\title{
In Vitro Evaluation of the Shear Bond Strength of Different Luting Cements on Zirconium Oxide Specimens in Primary Teeth
}

\section{Süt Dişlerinde Farklı Yapıştırma Materyalleriyle Uygulanan Zirkonyum Oksit Örneklerin Bağlanma Dayanımının ín Vitro İncelenmesi}

(1) Zekiye EFE, iD Zeynep Aslı GÜÇLÜ

Erciyes University Faculty of Dentistry, Department of Pedodontics, Kayseri, Turkey

\begin{abstract}
Objective: Nowadays in pediatric dentistry clinics, zirconia crowns have become widespread restoration choice of primary teeth with extensive decay. Aim of this study was to evaluate shear bond strength of different luting cements on zirconium oxide (zirconia) specimens in primary teeth.

Methods: Eighty extracted primary molar teeth were selected for the study and teeth were randomly divided into four groups. Eighty zirconium oxide specimen were fabricated using CAD/CAM technology. Samples were cemented with zinc polycarboxylate cement (PK), conventional glass ionomer cement (GCIS), resin modified GCIS (RMCIS) and self adhesive resin cement (RS). After cementation, samples were kept in distilled water for three days at room temperature. Then speciemens were subjected to 1000 cycles thermal cycle process. Shear bond strength was determined using universal testing machine, debonded surfaces were examined using stereomicroscope. Tamhane's test was used for pairwise comparisons of the mean bonding forces of the groups. Pearson chi-square test was used to compare the debonded surfaces. Significance level (p) was accepted as 0.05 in the application of the tests.

Results: Mean bond strength of RMCIS group was statistically lower than RS, GCIS and PK cements $(\mathrm{p}<0.05)$. There wasn't statistically significant difference between mean bonding strength of RS, GCIS and PK cement group ( $p>0.05$ ). There wasn't statistically significant difference between debonded surfaces of zirconia specimen after cementation with different bonding cements $(\mathrm{p}>0.05)$.
\end{abstract}

\section{ÖZ}

Amaç: Son yıllarda çocuk diş hekimliğinde aşırı madde kaybı görülen süt dişlerinin restorasyonunda zirkonya kronların kullanımı yaygınlaşmaktadır. Çalışmamızda zirkonyum oksit (zirkonya) örneklerin farklı yapışırıma materyalleriyle kullanımlarının süt dişlerine bağlanma kuvvetine etkisinin değerlendirilmesi amaçlandı.

Yöntemler: Çalışmada 80 adet çekilmiş süt azı dişi, her grupta yirmi diş olacak şekilde rastgele dört gruba ayrıldı. Seksen adet zirkonya örnek CAD/CAM kullanılarak üretildi. Örnekler çinko polikarboksilat siman (PK), geleneksel cam iyonomer siman (GCIS), rezin modifiye cam iyonomer siman (RMCIS) ve self adeziv rezin siman (RS) ile simante edildi. Simantasyon sonrası örnekler, distile su içerisinde oda sıcaklğı̆nda üç gün bekletildi. Sonrasında 1000 devir termal döngü işlemine tabi tutuldu. Termal döngü sonrası, bağlanma dayanımları üniversal test cihazında ölçüldü. Kopma yüzeyleri, ışık mikroskobunda incelendi. Grupların ortalama bağlanma kuvvetlerinin ikili karşslaştırılmasında Tamhane's testi kullanıldı. Kopma yüzeylerinin karş̧ılaştırılmasında ise Pearson kikare testi kullanıldı. Testlerin uygulanmasında anlamlılık düzeyi $(\mathrm{p}>0,05)$ olarak kabul edildi.

Bulgular: Çalışma sonunda RMCIS grubunun ortalama bağlanma kuvveti RS, GCIS ve PK siman göre daha düşük bulundu $(\mathrm{p}<0,05)$. RS, GCIS ve PK siman grubunun ortalama bağlanma kuvveti arasında istatistiksel olarak fark bulunmadı ( $p>0,05)$. Zirkonya örneklerin, farklı yapıştırma simanlarıyla simantasyonu sonrası kopma yüzeyleri arasında istatistiksel olarak anlamlı farklılık bulunmadı $(\mathrm{p}>0,05)$.

Address for Correspondence: Zekiye EFE, Erciyes University Faculty of Dentistry, Department of Pedodontics, Kayseri, Turkey

E-mail: zekiyehidayet@hotmail.com ORCID ID: orcid.org/0000-0001-5621-5279 
Conclusion: We think that it may be more advantageous to adhere zirconia crowns with self adhesive RS in pediatric patients whom are difficult to provide moisture control.

Keywords: Luting cement, retention, posterior primary teeth, zirconia
Sonuç: Nem kontrolünün sağlanması zor olan çocuk hastalarda zirkonya kronların self adeziv rezin siman ile yapıştırılmasının daha avantajlı olabileceğini düşünüyoruz.

Anahtar Sözcükler: Retansiyon, süt azı dişleri,yapıştırma simanı, zirkonya

\section{Introduction}

The choice of restorative materials in deciduous dentition differs compared to permanent dentition. Primary teeth are smaller in size compared to permanent teeth, and the thickness of enamel and dentin is thin, causing the remaining support structure to become weaker after the treatment $(1,2)$. Therefore, the possibility of microleakage and brittleness increases in the long term in large-restorated deciduous teeth (3). The application of resin-based materials in large masses in the restoration of primary teeth with excessive material loss causes an increase in polymerization shrinkage and deterioration of restoration compliance (4). In order to eliminate these negative situations, it is important that the physical and mechanical properties of the restorative material are close to the natural tooth structure, biocompatible and do not require regeneration until the time of physiological fall $(4,5)$.

In clinical studies, the use of prefabricated crowns in the restoration of primary teeth with excessive material loss has significantly reduced the causes of failure seen in other restorative materials in the long term $(4,6)$. Nowadays, stainless steel crowns (STC) and zirconium oxide (zirconia) crowns are used as prefabricated crowns in pediatric dentistry.

In recent years, the use of zirconia crowns, which do not have aesthetic concerns instead of STC and have characteristics close to natural tooth structure, has become widespread (5). Studies have reported that zirconia crowns are clinically successful restorations and their use increases aesthetic satisfaction $(7,8)$. The fact that zirconia restorations are biocompatible and exhibit excellent aesthetic and mechanical properties have enabled them to be used in pediatric dentistry as well as in many areas of dentistry (9).

The most important cause of clinical failure of prefabricated crowns is microleakage due to marginal edge opening (10). Although the contour harmony of the STC at the gum level is provided with various forceps, gaps between the tooth and the crown may remain. These openings are covered with adhesive cements. In a study, it has been shown that microleakage occurs in the area close to the gingiva border, even in STC that are perfectly matched to the extracted teeth and adhered with traditional glass ionomer cement (11). The microleakage resistance of the bonding cement used directly affects crown retention (12). The presence of an ideal cementation material that provides adaptation between the restoration and the tooth and increases the bond strength is important in the clinical success of prefabricated crowns $(13,14)$. Although it has been reported in the literature that zirconia crowns can be cemented with different bonding materials, there is no definitive explanation about the ideal cementation material to be used in primary teeth $(13,14)$. Therefore, in our study, it was aimed to evaluate the bonding strength of zirconia samples cemented with different bonding cements to primary teeth.

\section{Methods}

The study was approved by the Erciyes University Faculty of Medicine Ethics Committee on 20.06.2018 and the decision number was 2018/314. This study was supported by the Scientific Research Projects Unit of Erciyes University with the project coded TDH-2018-8332.

\section{Selection of Primary Teeth Suitable for Inclusion Criteria}

\section{Inclusion Criteria in the Study}

The extracted teeth belonging to the children of the parents who read and accepted the working conditions and signed the consent form were included in the study. In the study, primary molars without caries and/or with enamel caries with an indication of extraction due to periodontal or orthodontic reasons and near physiological fall time were used.

\section{The Criteria for Exclusion from the Study}

Teeth belonging to children whose parents did not sign the consent form were not included in the study. Among the teeth belonging to the children of the parents who accepted to participate in the study, primary molars with hypoplasia or deep caries, and cracked or broken primary molars were excluded from the study.

\section{Collection and Preparation of Primary Teeth}

Eighty extracted primary molars meeting the inclusion criteria were kept in $0.5 \%$ chloramine solution for one month in order to provide disinfection. Teeth were embedded in pressurecured white acrylic (Orthocryl ${ }^{\circledR}$ EQ, Dentaurum, Germany) in standard molds $(2.5 \times 1.5 \times 1.5 \mathrm{~cm})$ with their buccal or lingual surfaces exposed. Acrylic hardening was achieved under heat and pressure. The exposed surface of each specimen was then smoothed under water in a sanding and polishing device (Tegrapol-11, Struers, Denmark) with 220 and 400 grit silicon carbide to obtain a flat dentine surface parallel to the long axis of the tooth. Afterwards, the polishing process was completed with 600 grit silicon carbide to ensure the formation of a standard smear layer in each sample. 


\section{Preparation of Zirconia Specimens}

The zirconia structures used in the study were obtained from pre-sintered Katana zirconia blocks (Kuraray Noritake Inc., Kurashiki, Japan). The dimensions of the zirconia samples were designed to be $3 \mathrm{~mm}$ in diameter and $6 \mathrm{~mm}$ in length after sintering. Designs were prepared using DWOS ${ }^{\circledR}$ (Dental Wings Open System) computer-aided design (CAD) software. Eighty samples were designed and produced by using computer aided manufacturing (CAM) (CAM Yenadent DC40, Yenadent Ltd., Istanbul, Turkey) (Figure 1, 2). Since the zirconia structures showed $20 \%$ shrinkage linearly after the sintering process, the samples were designed at this rate than the specified dimensions. Afterwards, it was sintered at $1500^{\circ} \mathrm{C}$ for 2 hours in the sintering furnace (Programat CS4, Ivoclar Vivadent, Germany) in line with the manufacturer's recommendations.

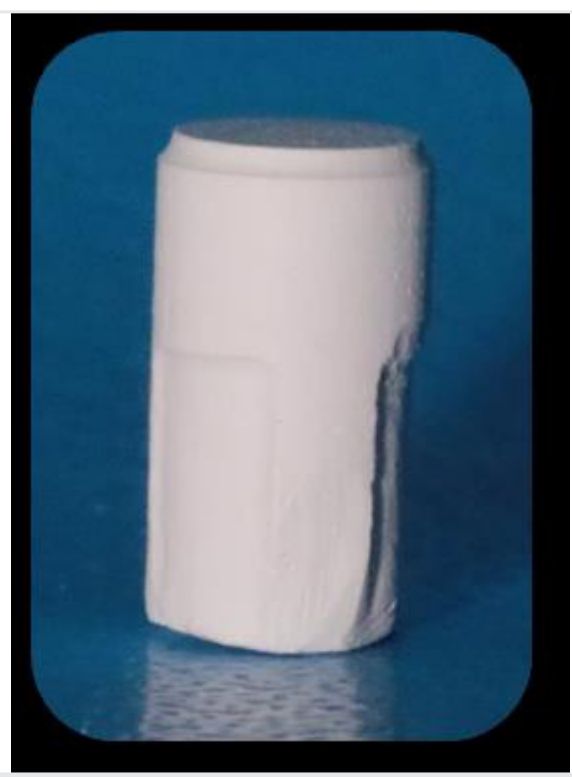

Figure 1. Side view of zirconia sample produced with CAM

\section{Cementation Procedures}

Each group was divided into four groups as 20 randomly distributed zirconia samples and 20 prepared teeth. Samples divided into four groups were cemented under finger pressure with conventional glass ionomer luting cement (GCIS), resin modified GCIS (RMCIS), zinc polycarboxylate cement (PK) and self-adhesive resin cement (RS) prepared in accordance with the manufacturer's instructions (Figure 2). Table 1 contains information about the luting cements used.

\section{Thermal Cycling of Samples}

Samples whose hardening were completed after cementation were stored in distilled water in their own closed collection containers for three days at room temperature. Subsequently, the samples in each group were placed in thin water-permeable sheaths and their mouths were tied with ribbons of different colors. The covers were placed horizontally in the water tanks. They were

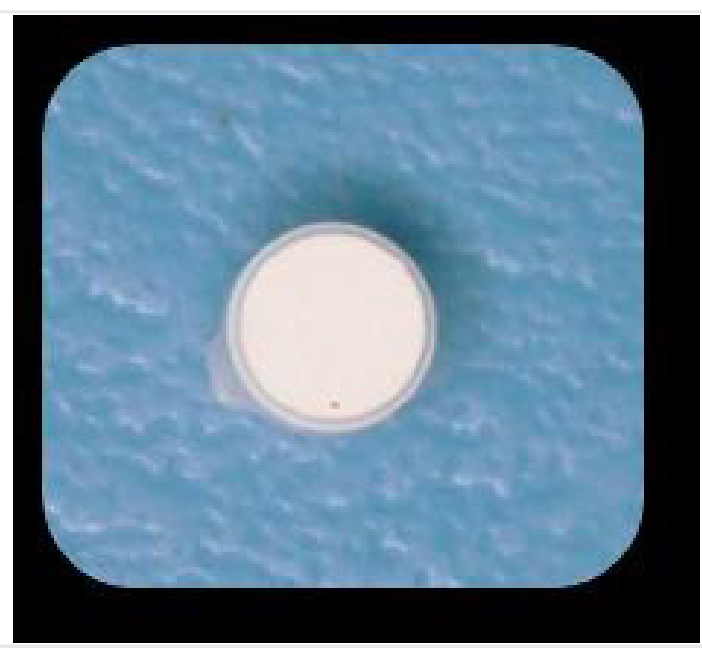

Figure 2.The cementation surface of the zirconia sample before sintering and the side view of the cemented sample

Table 1. Luting cements used in the cementation process

\section{Material class}

Zinc polycarboxylate cement

Conventional glass ionomer luting cement

Resin modified glass ionomer luting cement

Self adhesive resin cement
Materiel, manufacturer

Adhesor Carbofine, Spofa Dental, Germany

Meron, Voco, Cuxhaven, Germany

Meron Plus, Voco, Cuxhaven, Germany

R \& D Series Nova Resin Cement, Imicryl, Konya, Turkey
Lot number

Method of application

$6009542-1$

1410392

1810042

18087 minutes. is.
Two parts powder and five drops of liquid were mixed for 30 seconds. Working time at room temperature was 2 minutes, hardening time was 5-8 minutes.

One part powder and one drop of liquid were mixed for 30 seconds. Working time at room temperature was approximately 3 minutes, hardening time was 5-7

One part powder and two drops of liquid were mixed for 30 seconds. Working time at room temperature was about 2-4 minutes, hardening time was 3-5 minutes. is.

The cement, which was squeezed equally from the base and catalysis syringes, was mixed for 15 seconds. After removing the excess cement applied, it was polymerized by applying visible light for 20 seconds from each surface of the samples. 
subjected to 1000 cycle thermal cycling process (Jubalo FT400, Seelbach, Germany) with a waiting time of 20 seconds and a transfer time between tanks of 10 seconds in tanks containing water at $5 \pm 1{ }^{\circ} \mathrm{C}$ and $55 \pm 1{ }^{\circ} \mathrm{C}$. After the thermal cycle, samples were kept in distilled water in collection containers for 24 hours at room temperature.

\section{Measurement of Bonding Strength}

The long axis of the teeth were fixed between the holding arms of the universal testing device (Instron 3345, Instron Corp., Norwood, USA) parallel to the direction of the applied force (Figure 3). The blade edge of the device was positioned in contact with the fixed sample (Figure 4). The crosshead speed of the device was set at $0.5 \mathrm{~mm} / \mathrm{min}(15,16)$. Shear force was applied until separation occurred from the midpoint of the bonding area between the zirconia specimen and the dentin surface. The maximum force value obtained at the end of the test was recorded in Newton $(\mathrm{N})$. The same procedure was applied for all samples in four groups.

\section{Evaluation of Debonded Surfaces}

The debonded surfaces were examined by the same investigator at x40 magnification under a light microscope (Leica Optical Microscope, Leica Cambridge Ltd., Cambridge, UK). The debonded surfaces were classified as adhesive, cohesive and adhesive-cohesive (mixed) type debonding.

\section{Statistical Analysis}

Statistical Package for Social Sciences (SPSS Inc., Chicago, IL, USA) Windows 16.0 program was used for the statistical analysis of the data. The mean, standard deviation, minimum and

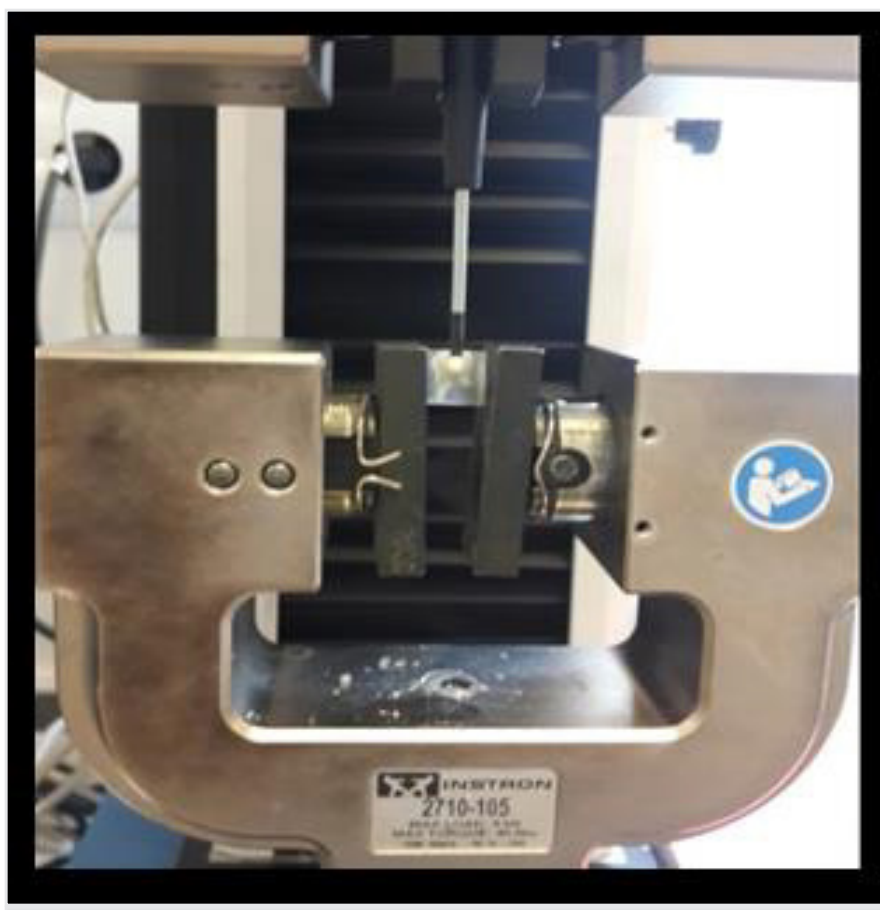

Figure 3. Instron universal test device and a sample put into the device maximum values of each experimental group were calculated. Kolmogorov-Smirnov test was used to examine the normal distribution and it was found that the data were not normally distributed $(\mathrm{p}=0.002)$. Therefore, the nonparametric KruskalWallis test was used to evaluate whether there was a difference between the mean bond strengths of the groups. The Tamhane's test was used for pairwise comparison of the average bond strengths of the groups. Pearson's chi-square test was used to compare the debonded surfaces. The significance level (p) in the application of the tests was accepted as 0.05 .

\section{Results}

\section{Bonding Strength Results}

Table 2 shows the average bond strength, standard deviation, minimum and maximum values of each experimental group (Table 2). According to the results of the Kruskal-Wallis test, a statistically significant difference was found between the means of bond strength of the groups $(\mathrm{p}=0.002)$ (Table 3$)$. The Tamhane's test was used in paired comparisons to determine from which groups the differences between groups arised (Table 4). There was no statistically significant difference between the average bond strength of the self-adhesive RS, GCIS and PK cement groups ( $p>0.05)$. However, the bond strength average of the RMCIS group was found to be significantly lower than the self-adhesive RS, GCIS and PK cemented groups ( $\mathrm{p}<0.05)$.

\section{Debonded Surface Results}

Debonding types are classified as adhesive, cohesive and mixed debondings. The debonding type between the luting cement and

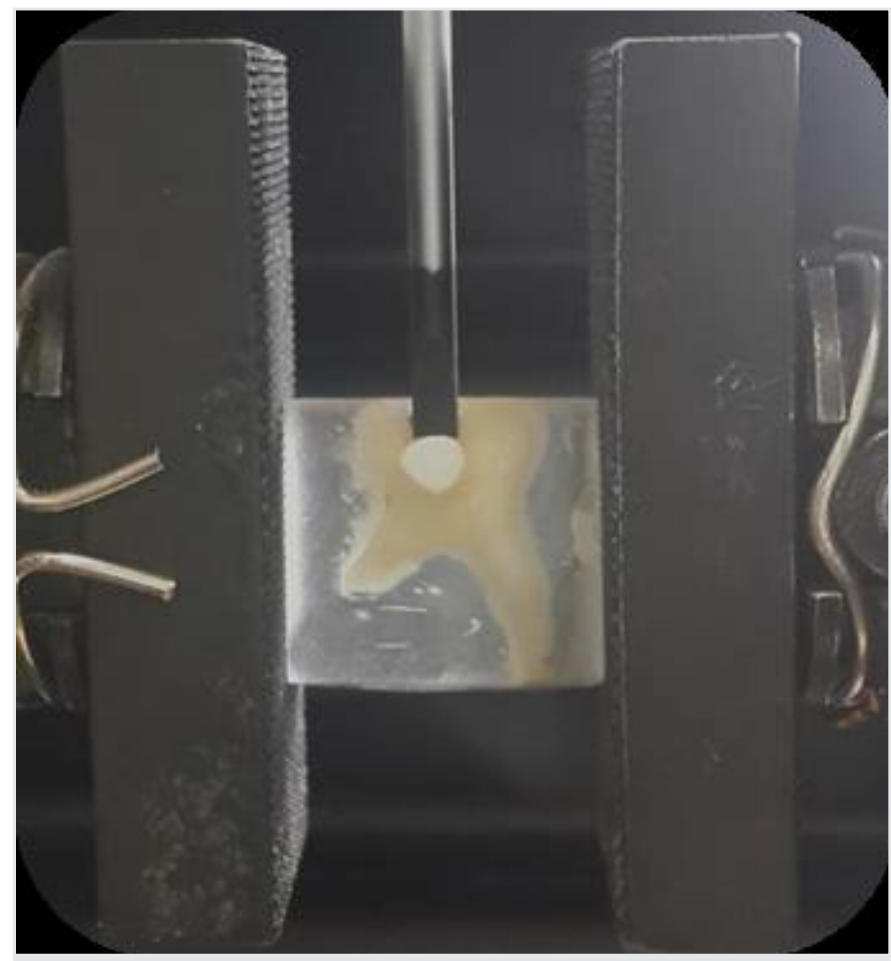

Figure 4. Close-up view of the sample placed in the test device 
Table 2. Descriptive values of the bond strengths $(\mathrm{N})$ of the experimental groups ( $\mathrm{n}$ : number of samples)

\begin{tabular}{|c|c|c|c|c|c|}
\hline Luting cements & $\mathrm{n}$ & Mean & Std. deviation & Minimum & Maximum \\
\hline RS & 20 & 27,222 & 11,864 & 9,00 & 47,18 \\
\hline RMCIS & 20 & 15,011 & 5,319 & 5,65 & 24,00 \\
\hline GCIS & 20 & 23,162 & 8,094 & 10,00 & 39,13 \\
\hline PK & 20 & 27,540 & 13,521 & 9,00 & 46,82 \\
\hline Total & 80 & 23,234 & 11,235 & 5,65 & 47,18 \\
\hline
\end{tabular}

Std. deviation: Standard deviation, RS: Resin cement, RCIMS: Resin modified GCIS, GCIS: Glass ionomer cement, PK: Polycarboxylate cement

Table 3. Comparison of bonding strengths ( $N)$ of the experimental groups (Kruskal-Wallis test, $p<0.05)(n:$ number of samples)

\begin{tabular}{|c|c|c|c|c|}
\hline Luting cements & $\mathrm{n}$ & Std. deviation & $x^{2}$ & $p$ value \\
\hline RMCIS & 20 & \multirow{3}{*}{2} & \multirow{3}{*}{14,868} & \multirow{3}{*}{$0,002^{*}$} \\
\hline GCIS & 20 & & & \\
\hline PK & 20 & & & \\
\hline
\end{tabular}

Table 4. Paired comparison of bond strengths $(N)$ of the experimental groups (Tamhane's test, $p<0.05$ )

\begin{tabular}{|c|c|c|c|}
\hline (I) Luting cement & (J) Luting cement & Mean difference (I-J) & $\mathrm{p}$ value \\
\hline \multirow[b]{2}{*}{ RS } & RMCIS & 12,211 & $0,002 *$ \\
\hline & GCIS & 4,060 & 0,766 \\
\hline \multirow[b]{2}{*}{ RMCIS } & RS & $-12,211$ & $0,002 *$ \\
\hline & GCIS & $-8,151$ & $0,004 *$ \\
\hline \multirow{3}{*}{ GCIS } & RS & $-4,060$ & 0,766 \\
\hline & RMCIS & 8,151 & $0,004 *$ \\
\hline & PK & $-4,378$ & 0,781 \\
\hline PK & RS & 0,318 & 1,000 \\
\hline
\end{tabular}

Std. deviation: Standard deviation, RS: Resin cement, RCIMS: Resin modified GCIS, GCIS: Glass ionomer cement, PK: Polycarboxylate cement

the bonding surfaces is called adhesive type, debonding inside the luting cement is called cohesive type, and the debonding type that involves adhesive and cohesive debondings is called mixed type (17). Table 5 shows the distribution rates of the debonding types according to the experimental groups. No statistically significant difference was found between the debonded surfaces of zirconia samples after cementation with different luting cements $(\mathrm{p}=0.497)$.

\section{Discussion}

With the increasing demand for aesthetic restoration in pediatric dentistry, the use of zirconia crowns is becoming widespread (8).
However, the presence of cementation material, which positively affects the bond strength, is one of the important factors in the long-term success of crowns $(13,14)$. In this study, the bond strength of these four widely used cementation materials to zirconia samples was investigated. As a result, no significant difference was found between the average bond strength of selfadhesive RS, GCIS and PK cements. The RMCIS group, on the other hand, showed the lowest bond strength average.

In the literature, there are studies on the bond strength of zirconia crowns applied with different bonding cements to permanent teeth $(18,19)$. Palacios et al. (19), cemented them with RS (Panavia F 2.0), self-adhesive RS (Rely X Unicem) 
Table 5. Distribution of debonding types according to experimental groups (n: sample number)

\begin{tabular}{|c|c|c|c|}
\hline \multirow[b]{2}{*}{ Luting cement } & \multicolumn{3}{|c|}{ Debonding ( $n(\%))$} \\
\hline & Adhesive & Mixed & Cohesive \\
\hline RS & $14(70)$ & $6(30)$ & $0(0)$ \\
\hline RMCIS & $16(80)$ & $3(15)$ & $1(5)$ \\
\hline GCIS & $15(75)$ & $5(25)$ & $0(0)$ \\
\hline PK & $13(65)$ & $5(25)$ & $2(10)$ \\
\hline
\end{tabular}

and RMCIS (Rely X Luting) after abrading the inner surface of zirconia crowns produced with CAD/CAM with aluminum oxide particles in their in vitro study on permanent molars. The samples were subjected to tensile testing after 5,000 cycles of thermal cycling. As a result, it was shown that there was no statistically significant difference between the average bond strength of three different adhesive cement. In our study, the average bond strength of zirconia samples cemented with selfadhesive RS was found to be significantly higher than the RMCIS group. We think that the differences between the results may be due to the use of primary teeth in our study, the fact that zirconia samples are not in the form of crowns, and the difference in cement brands. In addition, in some studies, it has been reported that RMCISs show higher bond strength on the permanent tooth dentin surface compared to primary teeth (2022). This is explained by the fact that the peritubular area of the primary tooth dentin is thicker than the permanent tooth, that the intertubular dentin covers less volume, and that the calcium level decreases as it approaches the pulp (23).

In an in vitro study performed on primary molar teeth (10), the adapted SCT as a result of the preparations made on the teeth were cemented with RS (Panavia F), RMCIS (Rely X Luting) and GCIS (Aqua Meron). Tensile test was applied to samples that were kept in distilled water for 24 hours after cementation. According to the results of that study, no statistically significant difference was found between the bond strength averages of the RS and GCIS groups. It was reported that the RMCIS group showed the lowest bond strength average. In addition, in scanning electron microscopy examinations, it was shown that there was a good adaptation between tooth structure and SCT in samples cemented with RS. The results of that study were in agreement with the results of our study.

In another in vitro study, RMCIS (Rely X Luting), self-adhesive RS (Clearfil SA) and GCIS (Kavitan Cem) were applied to the enamel and dentin surfaces of primary teeth in standard sizes. Samples waiting in distilled water for 24 hours after the application were subjected to shear test and the debonded surfaces were evaluated. As a result of the study, it was reported that the bond strength of GCIS to primary tooth enamel was significantly lower compared to RMCIS and self-adhesive RS. In addition, there was no statistically significant difference between the average bond strength of three different bonding cements to primary tooth dentin. It was reported that the application of a surface conditioning agent such as polyacrylic acid on the dentine surface before the use of RMCIS and GCIS increased the wettability and bond strength by decreasing the surface tension (24). In the GCIS and self-adhesive RS groups, adhesive-type debonding was observed at a rate of $90-100 \%$, and mixed-type debonding was observed at a rate of $50 \%$ in the RMCIS group (24). In our study, there was no difference between the average bond strength of the self-adhesive RS and GCIS groups, but the adhesive type debonding was higher in both groups compared to the other debonding types. However, the lowest bond strength average was found in the RMCIS group, and a higher rate of adhesive type debonding was also observed in this group. The differences between the RMCIS groups were due to the different brand and polymerization type of RMCIS used in our study, the difference in the cementation surfaces and the samples not subjected to thermal cycling in the study by Dadakoglu et al. (24).

The bond strength is affected by the polymerization type of cement (18). The polymerization type determines the degree to which the cement is affected by the moisture and saliva in the mouth in the early period after cementation. Visible light or dual-curing cements are not affected much by moisture in the early stages of cementation compared to conventional cements (16). This situation prevents the reduction of crown retention in the early period after cementation, especially in pediatric patients. The fact that GCIS is sensitive to moisture in the initial hardening and its solubility increases in the case of contamination cause a decrease in bond strength (25). RMCIS was produced in order to eliminate these disadvantages. However, due to the fact that the hydroxymethylmethacrylate (HEMA) in the structure is a hydrophilic monomer, the water absorption property of the material is increased. Although initially water absorption seems to compensate for polymerization shrinkage, it has been reported that it negatively affects the mechanical properties in the long term (26).

\section{Study Limitations}

In in vitro studies on the retention of cements, imitation of intraoral conditions facilitates the reflection of study results to clinical practice (18). One of the limitations of this study was that the study was performed under static conditions. 
Finger pressure applied to stabilize the zirconia samples during the cementation phase did not provide a standard loading. In addition, the samples were thermally cycled in distilled water, which did not fully represent the dynamic environment of the oral cavity. Applying tensile and shear forces in conditions where samples are subjected to dynamic loading in artificial saliva will provide better imitation of intraoral conditions.

\section{Conclusion}

In the study, the bond strength of zirconia specimens cemented with different luting cements on the primary tooth dentin surface were evaluated. Considering the results within the limitations of this in vitro study, it was found that the bonding of zirconia crowns with self-adhesive RS, GCIS and PK cement did not cause a difference in bond strength. We think that bonding prefabricated zirconia crowns with self-adhesive RS may provide ease of clinical application compared to chemically cured GCIS and PK cement in children whose treatment periods are not too long and in whom moisture control is difficult. However, we are of the opinion that the issue should be supported by long-term clinical studies.

\section{Ethics}

Ethics Committee Approval: Ethics committee approval was given by Erciyes University Faculty of Medicine (date: 12.06.2018).

Informed Consent: Obtained.

Peer-review: Externally peer reviewed.

\section{Authorship Contributions}

Surgical and Medical Practices: Z.E., Concept: Z.E., Z.A.G., Design: Z.E., Z.A.G., Data Collection or Processing: Z.E., Analysis or Interpretation: Z.E., Z.A.G., Literature Search: Z.E., Writing: Z.E.

Conflict of Interest: No conflict of interest was declared by the authors.

Financial Disclosure: This study was supported by the Scientific Research Projects Unit of Erciyes University with the project coded TDH-2018-8332.

\section{References}

1. Griffin SO, Gooch BF, Beltran E, Sutherland JN, Barsley R. Dental services, costs, and factors associated with hospitalization for medicaid-eligible children, Louisiana 1996-97. Journal of Public Health Dentistry 2000 Winter;60:21-7.

2. Misra S, Tahmassebi JF, Brosnan M. Early childhood caries-a review. Dental Update 2007;34:556-64.

3. Oueis H, Atwan S, Pajtas B, Casamassimo PS. Use of anterior veneered stainless steel crowns by pediatric dentists. Pediatric Dentistry 2010;32:413-6.

4. Eidelman E, Faibis S, Peretz B. A comparison of restorations for children with early childhood caries treated under general anesthesia or conscious sedation. Pediatric Dentistry 2000;22:33-7.
5. Kagihara LE, Niederhauser VP, Stark M. Assessment, management, and prevention of early childhood caries. Journal of the American Academy of Nurse Practitioners 2009;21:1-10.

6. Blatz MB. Long-term clinical success of all-ceramic posterior restorations. Quintessence International 2002;33:415-26.

7. MacLean JK, Champagne CE, Waggoner WF, Ditmyer MM, Casamassimo P. Clinical outcomes for primary anterior teeth treated with preveneered stainless steel crowns. Pediatric Dentistry 2007;29:377-81.

8. Shah PV, Lee JY, Wright JT. Clinical success and parental satisfaction with anterior preveneered primary stainless steel crowns. Pediatric Dentistry 2004;26:391-5.

9. Vagkopoulou T, Koutayas SO, Koidis P, Strub JR. Zirconia in dentistry: Part 1. Discovering the nature of an upcoming bioceramic. The European Journal of Esthetic Dentistry 2009;4:130-51.

10. Yilmaz Y, Dalmis A, Gurbuz T, Simsek S. Retentive force and microleakage of stainless steel crowns cemented with three different luting agents. Dental Materials Journal 2004;23:577-84.

11. Guelmann M, Bookmyer KL, Villalta P, Garcia-Godoy F. Microleakage of restorative techniques for pulpotomized primary molars. Journal of Dentistry for Children 2004;71:209-11.

12. Nash DA. The nickel-chromium crown for restoring posterior primary teeth. Journal of the American Dental Association. 1981;102:44-9.

13. Burke FJ, Fleming GJ, Nathanson D, Marquis PM. Are adhesive technologies needed to support ceramics? An assessment of the current evidence. The Journal of Adhesive Dentistry 2002;4:7-22.

14. Gorodovsky S, Zidan O. Retentive strength, disintegration, and marginal quality of luting cements. The Journal of Prosthetic Dentistry 1992;68:269-74.

15. Pekkan G, Hekimoglu C. Evaluation of shear and tensile bond strength between dentin and ceramics using dual-polymerizing resin cements. The Journal of Prosthetic Dentistry 2009;102:242-52.

16. Somani R, Jaidka S, Singh DJ, Sibal GK. Comparative evaluation of shear bond strength of various glass ionomer cements to dentin of primary teeth: An in vitro Study. International Journal of Clinical Pediatric Dentistry 2016;9:192-6.

17. Marshall SJ, Bayne SC, Baier R, Tomsia AP, Marshall GW. A review of adhesion science. Dental Materials 2010;26:e11-6.

18. Ernst CP, Cohnen U, Stender E, Willershausen B. In vitro retentive strength of zirconium oxide ceramic crowns using different luting agents. The Journal of Prosthetic Dentistry 2005;93:551-58.

19. Palacios RP, Johnson GH, Phillips KM, Raigrodski AJ. Retention of zirconium oxide ceramic crowns with three types of cement. The Journal of Prosthetic Dentistry 2006;96:104-14.

20. Nor JE, Feigal RJ, Dennison JB, Edwards CA. Dentin bonding: SEM comparison of the dentin surface in primary and permanent teeth. Pediatric Dentistry 1997;19:246-52.

21. Yaseen SM, Subba Reddy VV. Comparative evaluation of shear bond strength of two self-etching adhesives (sixth and seventh generation) on dentin of primary and permanent teeth: an in vitro study. Journal of the Indian Society of Pedodontics and Preventive Dentistry 2009;27:33-8. 
22. Uekusa S, Yamaguchi K, Miyazaki M, Tsubota K, Kurokawa H, Hosoya Y. Bonding efficacy of single-step self-etch systems to sound primary and permanent tooth dentin. Operative Dentistry 2006;31:569-76.

23. Courson F, Bouter D, Ruse ND, Degrange M. Bond strengths of nine current dentine adhesive systems to primary and permanent teeth. Journal of Oral Rehabilitation 2005;32:296-303.

24. Dadakoglu N, Tuna AN, Aras S. Farklı yapıdaki yapıştırma simanlarının süt dişi mine ve dentinine bağlanmasının in vitro koşullarda değerlendirilmesi. Turkiye Klinikleri J Dental Sci 2012;18:269-76.

25. Caughman WF, Caughman GB, Dominy WT, Schuster GS. Glass ionomer and composite resin cements: effects on oral cells. The Journal of Prosthetic Dentistry 1990;63:513-21.

26. Yap A, Lee CM. Water sorption and solubility of resin-modified polyalkenoate cements. Journal of Oral Rehabilitation 1997;24:3104 . 